\title{
ESTIMATION OF LOSSES IN UKRAINE DUE TO UNEMPLOYMENT
}

\author{
Liudmyla Chernetska'
}

\begin{abstract}
One of the most important criteria, which makes it possible to evaluate the consequences and prospects of the country's development positively, is the dynamic growth of its economy, which is initiated, first of all, by increasing the efficiency of utilization in the national production of human resources. However, their productive implementation is affected by many socio-economic problems, including unemployment. In the economy, unemployment is a reflection of the state of the labor market, which characterizes the balance of supply and demand for jobs, in the social sphere it is one of the main factors for obtaining a stable income. Loss of work leads not only to a decrease in the current material standard of living, but also to the appearance of uncertainty in the future, as well as to the emergence of feelings of inferiority. Because people who want to work but do not have a job, they are not able to contribute to the increase of production of goods and services. The number of unemployed in the country is another indicator of its economic disadvantage. Therefore, unemployment is constantly the focus of government regulation of the economy and the labor market, and the instruments of regulation and its consequences are evolving with the development of socio-economic relations. The aim of the study. This research article is aimed at determining the macroeconomic losses caused by unemployment, taking into account age and gender. This gives a clearer picture of the magnitude of the likely benefit from properly formed and effectively implemented investment in programmatic measures to reduce unemployment as part of the formation of national economic growth strategies. Methodology. The analysis uses a multiplicative model of economic growth that describes the dependence of GDP growth on exogenous factors - the growth rate of gross fixed capital formation and the growth rate of those employed in the economy over the same period. The differences in this part are the use of more accurate data on labor costs: the number of employees is adjusted by gender and age coefficients of labor productivity. Results. The dynamics of the unemployment rate in Ukraine over the last years in terms of gender and age and duration of unemployment are analyzed on the basis of statistics. Based on the constructed production function, the estimation of the potential level of GDP output and the magnitude of its non-receipt in Ukraine due to excess of actual unemployment above its natural level for the period from 2010 to 2016 was made. The resulting production function model can also be applied to predict future GDP values based on the expected levels of fixed capital and the number of employees by age.
\end{abstract}

Key words: age structure of the population, coefficients of productivity, the Cobb-Douglas production function, potential GDP, GDP gap.

JEL Classification: E23, E24, C51, 011

\section{Introduction}

Unemployment is one of the most acute socioeconomic problems in the de-velopment of the modern Ukrainian economy. It is caused by both objective and subjective circumstances. On the one hand, this is an indispensable phenomenon in the development of a market system when it comes to the minimum unemployment rate in a country that cannot be reduced and corresponds to the concept of full employment. On the other hand, when the unemployment rate exceeds the natural level, there are processes of inefficient use of labor in the national economy.

Despite the considerable development of the problem of unemployment, it should be acknowledged that the emergence of new factors that determine its manifestation in new forms requires the deepening of theoretical knowledge in the field of study of this major socio-economic phenomenon of the labor market. In particular, the improvement of methodological instruments of quantitative measurement of the economic

Corresponding author:

${ }^{1} \mathrm{SO}$ "Institute for Economics and Forecasting of NAS of Ukraine", Ukraine.

E-mail: ludmilacernecka@gmail.com

ORCID: https://orcid.org/0000-0002-6622-6964 
consequences of unemployment to form an objective basis for its state and dynamics, in order to select adequate directions of prevention and regulation of its consequences.

It is known that the population at different ages (in particular, and in the middle of the working period) differs both in physical strength and skill, as well as in the level of knowledge, experience, etc. This explains the need to find a more comprehensive assessment of the economic losses caused by unemployment taking into account the importance of age and gender for the country's economy. This determines the relevance and choice of the topic, setting the purpose and objectives of this study: to conduct, using both traditional and new tools, economic and statistical analysis of unemployment in modern Ukraine and quantify the economic consequences of unemployment for the state.

\section{Analysis of the unemployment rate in Ukraine}

The conducted researches of the labor market of Ukraine and social and labor relations show that the reforms carried out did not fully contribute to the formation of positive tendencies in the labor market of Ukraine. From 2010 to 2013 in Ukraine, there was a gradual decrease in unemployment rates (overall from $8.2 \%$ in 2010 to $7.3 \%$ in 2013; for men from $9.4 \%$ to $8.1 \%$; for women from $8.2 \%$ to $7.3 \%)$. Further, by 2017 , these figures rose sharply (overall up to $9.5 \%$; for men up to $11.1 \%$; for women up to $7.7 \%)$. And then they fell again in 2018, but only compared to 2014-2017, compared to 2010-2013, the figures are higher (Table 1). Thus, the unemployment rate in Ukraine is quite high, especially among men. In addition, despite high unemployment rates, confidence in the mediation services of the State Employment Center is low: only a third uses its services.

Unemployment is never evenly distributed among the population and by age group. Some people suffer from it more than others. Thus, in 2018, the overall unemployment rate in all youth age subgroups is higher than the average level in the economically active age $(8.8 \%)$ : the youth unemployment rate of 30-34 years old was $8.9 \%$; at the age of 25-29 years old was $9.8 \%$, and in the age group of 15-24 years old this indicator was at the level of $17.9 \%$, i.e., more than twice higher than among all economically active population. In addition, for women, the unemployment rate of the youngest age group was $19.3 \%$, which meant that one in five economically active women could not find a job after college. Overall, in 2018, among the unemployed, about $30 \%$ were in the youth group ( 15 to 29 years old), another $30.0 \%$ were in the 30-39 age group.

Long-term unemployment is still present in Ukraine. During 2010-2018, on average, a quarter of the unemployed have been seeking work for more than one year. Among such persons, the majority of young people are aged 15-34 and make up about $40 \%$. In particular, significant amounts of long-term unemployment are recorded in the age group of 30-34 years old, although persons from this age group usually exhibit higher than average employment rates, since most of them already have accumulated work experience, vocational skills, education and more. More than $75 \%$ of the unemployed in Ukraine are people with good education, who represent the best part of the labor potential of society but cannot realize it due to the complex socio-economic, socio-political and other factors that have developed in the country.

Table 1

Labor Market Indicators in Ukraine in 2010-2016

\begin{tabular}{|c|c|c|c|c|c|c|}
\hline \multirow[b]{2}{*}{ Years } & \multirow{2}{*}{$\begin{array}{c}\text { Economically } \\
\text { active population } \\
\text { of thousand people }\end{array}$} & \multirow{2}{*}{$\begin{array}{c}\text { Busy population } \\
\text { of thousand } \\
\text { people }\end{array}$} & \multirow{2}{*}{$\begin{array}{l}\text { Unemployed } \\
\text { population of } \\
\text { thousand people }\end{array}$} & \multicolumn{3}{|c|}{ Unemployment rate, $\%$} \\
\hline & & & & Total & Men & Women \\
\hline 2010 & 20894.1 & 19180.2 & 1713.9 & 8.2 & 9.4 & 6.9 \\
\hline 2011 & 20893.0 & 19231.1 & 1661.9 & 8.0 & 8.9 & 6.9 \\
\hline 2012 & 20851.2 & 19261.4 & 1589.8 & 7.6 & 8.7 & 6.5 \\
\hline 2013 & 20824.6 & 19314.2 & 1510.4 & 7.3 & 8.1 & 6.3 \\
\hline 2014 & 19920.9 & 18073.3 & 1847.6 & 9.3 & 1.9 & 7.6 \\
\hline 2015 & 18097.9 & 16443.2 & 1654.7 & 9.1 & 1.2 & 8.2 \\
\hline 2016 & 17955.1 & 16276.9 & 1678.2 & 9.3 & 1.9 & 7.8 \\
\hline 2017 & 17854.4 & 16156.4 & 1698.0 & 9.5 & 11.2 & 7.9 \\
\hline 2018 & 17939.5 & 16360.9 & 1578.6 & 8.8 & 10.1 & 7.5 \\
\hline
\end{tabular}

Note: all data excluding the Autonomous Republic of Crimea and the ATO zone 


\section{Age factor in economic growth}

One of the key methods of analyzing agespecific features of production and consumption, known as the "age-old economic pyramid", was proposed by E.Valkovich, who built age-scales of production intensity in Hungary in the 1960s of the 20th century (Valkovich, 1970). Subsequently, in 1975-1976, a survey was conducted in Latvia of the workers of the most important branches of material production, which made it possible to build age-specific production scales for the male and female population (Zvidrinysh, 1987). Similar results were obtained by M. Denysenko and A. Sagradov for Russia in the second half of the 1990s (Sagradov, 2005). In 1999, in the USA, in 2003 in New Zealand, new developments also emerged. Based on the analysis of data from sample surveys of households for the period from 2001 to 2003, the coefficients of labor contribution were also determined for Belarus (Ahabekova, 2006). They are all calculated in such a way that their values are the ratio of the productivity of one person of a certain age to the corresponding average level for the whole population. The results of these studies on the scale of productivity by age, we summarized in Table 2.

Comparing the indicators by periods of development, we can conclude that over the past decades, there has been a marked increase in the labor contribution of people aged 30 to 55 years old and a decrease in its indicators in the age group of 15-19 years old, which is due, first of all, to an increase in the period of youth education and, respectively, a later start of work.

\section{Construction of production function}

The simplest concept of economic growth is based on a common production function $\mathrm{Y}=\mathrm{F}(\mathrm{K}, \mathrm{L})$, according to which output $(\mathrm{Y})$ is determined by the contribution of factors of production - capital $(\mathrm{K})$ and labor $(\mathrm{L})$. These models are, for the most part, based on the Cobb Douglas production function:

$$
Y=A^{*} K^{a *} L^{\beta} \text {, }
$$

where $\mathrm{A}$ is the parameter that characterizes the level of technology - the joint productivity of capital and labor; $\alpha$ and $\beta$ are the factors that characterize the corresponding contribution of production factors to output growth.

Construction of the Cobb-Douglas production function for Ukraine was carried out as follows:

- Gross fixed capital formation (GFCF), hereinafter " $K$ ", was used to estimate the contribution of capital to GDP growth;

- "Effective employment" is used to measure labor $-L_{e f}$, that is, the number of persons of employment of the relevant age and $\operatorname{sex}\left(L_{s, x}\right)$ in the economy, taking into account their gender-age labor productivity $\left(q_{s, x}\right): L_{e f}=\sum_{x=15}^{70}\left(L_{x, s} * q_{x, s}\right)$, is simply " $L_{e f}$ ". Due to the lack of developments in Ukraine regarding labor productivity coefficients by demographic groups, for our calculations we used the coefficients constructed for the population of Belarus in 2001-2003 (table 2, column 7-8). We will look for a production function like this:

$$
\begin{aligned}
& \left(\frac{Y_{t}}{Y_{t-1}}\right)=A^{*}\left(\frac{K_{t}}{K_{t-1}}\right)^{\alpha} *\left(\frac{L_{e f t}}{L_{e f t-1}}\right)^{\beta}, \\
& \text { or } \Delta Y=A^{*} \Delta K^{\alpha *} \Delta L_{e f}^{\beta},
\end{aligned}
$$

Table 2

Scales of labor productivity according to various studies of the 20th-21 st century

\begin{tabular}{|c|c|c|c|c|c|c|c|}
\hline \multirow{2}{*}{ Age group } & \multirow{2}{*}{$\begin{array}{c}\text { Hungary } \\
(1960)\end{array}$} & \multicolumn{2}{|c|}{ Latvia $(1976)$} & \multirow{2}{*}{ USA (1999) } & \multirow{2}{*}{$\begin{array}{c}\text { New Zea-land } \\
(2003)\end{array}$} & \multicolumn{2}{|c|}{ Belarus (2001-2003) } \\
\cline { 7 - 9 } & men & women & & men & women \\
\hline 1 & 2 & 3 & 4 & 5 & 6 & 7 & 8 \\
\hline $15-19$ & 0.711 & 0.71 & 0.84 & 0.16 & 0.2 & 0.4 & 0.52 \\
\hline $20-24$ & 0.916 & 0.92 & 0.96 & 0.46 & 0.68 & 0.9 & 0.85 \\
\hline $25-29$ & 1.051 & 1.06 & 1.05 & 0.85 & 1.13 & 1.21 & 1.0 \\
\hline $30-34$ & 1.099 & 1.08 & 1.05 & 1.04 & 1.44 & 1.25 & 1.15 \\
\hline $35-39$ & 1.11 & 1.13 & 1.07 & 1.22 & 1.5 & 1.22 & 1.22 \\
\hline $40-44$ & 1.117 & 1.08 & 1.03 & 1.32 & 1.56 & 1.27 & 1.22 \\
\hline $45-49$ & 1.092 & 1.05 & 1.05 & 1.38 & 1.6 & 1.25 & 1.32 \\
\hline $50-54$ & 1.07 & 1.01 & 0.99 & 1.39 & 1.59 & 1.19 & 1.29 \\
\hline $55-59$ & 1.059 & 0.96 & 0.89 & 1.3 & 1.2 & 1.04 & 1.08 \\
\hline $60-64$ & 0.901 & 0.67 & 0.7 & 1.2 & 0.77 & 0.9 & 0.88 \\
\hline $65-69$ & 0.872 & 0.67 & 0.7 & 0.92 & 0.26 & 0.83 & 0.8 \\
\hline $70-79$ & 0.799 & 0.67 & 0.7 & 0.74 & 0.07 & 0.76 & 0.73 \\
\hline
\end{tabular}


where $\Delta \mathrm{Y}$ - the rate of GDP growth at constant prices, in \% compared to the previous year;

$\Delta \mathrm{K}$ - the rate of growth of the GNPC volume at constant prices, in \% com-pared to the previous year;

$\Delta \mathrm{L}$ - growth rate of "effectively employed", in \% compared to the previous year.

The output for constructing the production function is presented in Table 3.

The estimation of the parameters of the production function (2), in particular its linear form $\quad\left(\ln \Delta Y=\ln A+\alpha \ln \Delta K+\beta \ln \Delta L_{e f}\right)$, using the least squares method, showed that the free term is statistically insignificant $(\mathrm{t}$-statistic $=$ $-0,754<t_{\text {table }}$; standard error $=0,877 ; \mathrm{p}$-value $=$ $0,4702>0,05)$, so the function parameters were re-evaluated without a free term. The results of correlation-regression analysis are presented in Table 4.
Therefore, a high coefficient of determination $\mathrm{R}^{2}=0.939$, a slight regression error of $1.85 \%$, a considerable calculated value of the Fisher's test that exceeds the table value $\left(F_{\text {table }}=4,1\right)$, the Student's t-test of the parameters of the production function (coefficients of elasticity $\alpha$ i $\beta) t_{\alpha}=8,54$ mat $_{\beta}=35,014>t_{\text {table }}(2,262)$ and their P-values $(<0.05)$ indicate the significant adequacy and statistical significance of the whole model. And this confirms the correctness of the chosen relationship between the studied variables. The residuals are distributed by normal law, there is no autocorrelation and heteroscedasticity. Also, there is no collinearity between the explanatory variables $(R=0.504)$, and the relatively high values of the paired correlation coefficients $(\mathrm{R}>0.75)$ between the dependent variable and the explanatory variables confirm the informative nature of the latter. Performing an exponential

Table 3

Initial data for the production function

\begin{tabular}{|c|c|c|c|c|c|c|}
\hline \multirow{2}{*}{ Years } & \multicolumn{2}{|c|}{ GDP } & \multicolumn{2}{c|}{ GFCF } & \multicolumn{2}{c|}{$\begin{array}{c}\text { Average number of "effectively } \\
\text { employed" }\end{array}$} \\
\cline { 2 - 7 } & $\begin{array}{c}\text { million UAH, in } \\
2004 \text { prices. }\end{array}$ & Tempo growth & $\begin{array}{c}\text { million UAH, } \\
\text { in 2004 prices. }\end{array}$ & Tempo growth & $\begin{array}{c}\text { (Conditional } \\
\text { thousand people) }\end{array}$ & Tempo growth \\
\hline 2004 & 345113 & $\mathrm{X}$ & 77820 & $\mathrm{X}$ & 23101 & $\mathrm{X}$ \\
\hline 2005 & 355723 & 103.1 & 80804 & 103.8 & 23481 & 101.6 \\
\hline 2006 & 381618 & 107.3 & 98033 & 121.3 & 23530 & 100.2 \\
\hline 2007 & 411607 & 107.9 & 121342 & 123.8 & 23704 & 100.7 \\
\hline 2008 & 419715 & 102.0 & 119935 & 98.8 & 23797 & 100.4 \\
\hline 2009 & 359101 & 85.6 & 59847 & 49.9 & 22990 & 96.6 \\
\hline 2010 & 374349 & 104.2 & 62117 & 103.8 & - & - \\
\hline & Without the Autonomous Republic of Crimea, 2014-2016 also without the ATO zone & \\
\hline 2009 & - & - & - & - & 21954 & X \\
\hline 2010 & 373235 & X & 58294 & X & 21905 & 99.8 \\
\hline 2011 & 393637 & 105.5 & 63244 & 108.5 & 22013 & 100.5 \\
\hline 2012 & 393827 & 100.0 & 66383 & 105.0 & 22168 & 100.7 \\
\hline 2013 & 393861 & 100.0 & 60863 & 91.7 & 22214 & 100.2 \\
\hline 2014 & 368059 & 93.4 & 46284 & 76.0 & 20977 & 94.4 \\
\hline 2015 & 332045 & 90.2 & 42017 & 90.8 & 19118 & 91.1 \\
\hline 2016 & 339830 & 102.3 & 50451 & 120.1 & 18942 & 99.1 \\
\hline
\end{tabular}

Table 4

Indicators of correlation-regression analysis of the impact of the dynamics of GFCF and the number of "effectively employed" on GDP dynamics

\begin{tabular}{|c|c|c|c|c|}
\hline Equation & $\mathrm{R}^{2}$ & Reliability & Standard error & F-Fisher \\
\hline \multirow{3}{*}{$\begin{array}{c}\ln \Delta \mathrm{Y}= \\
0,201781 \ln \Delta \mathrm{K}+ \\
+0,801561 \ln \Delta \mathrm{L}+\varepsilon\end{array}$} & 0.939 & 0.95 & 0.0185 & 371567.4 \\
\hline & Rationed $\mathrm{R}^{2}$ & DW & $\Sigma \varepsilon^{2}$ & Significance $\mathrm{F}$ \\
\hline & 0.933 & 1.884 & 0.0034 & 0.00000 \\
\hline \multicolumn{2}{|c|}{ Odds } & Standard er-ror & t- statistics & P-value \\
\hline$\alpha$ & 0.201781 & 0.023627 & 8.540276 & 0.00000 \\
\hline$\beta$ & 0.801561 & 0.023566 & 34.01399 & 0.00000 \\
\hline
\end{tabular}


operation made it possible to obtain models of the following form:

$$
\Delta Y=\Delta K^{0,20} \Delta L_{e f}^{0,80}
$$

The values of the coefficients of elasticity show that: with a $1 \%$ increase in GDP, the GDP growth will be $\sim 0.20 \%$; with a $1 \%$ increase in the number of "effectively employed" in the economy, the real GDP growth will be $\sim 0.80 \%$.

When calculating the marginal rates of substitution of factors of production, it can be seen that in order for GDP not to decrease, the decrease in the number of "effectively employed" in Ukraine by $1 \%$ should be offset by a capital increase of $3.97 \%$. At the same time, in order for capital to grow, growth in aggregate demand, the main component of which is consumption, is required. As stated by J.M. Keynes, “...capital is not some intrinsic substance that is independent of consumption" (Keynes, 2002). Consumption, for its part, depends on the needs and financial capacity of the population, the latter of which is significantly dependent on the availability of a place of work in the able-bodied population.

\section{GDP gap due to unemployment}

Due to the fact that people who want to work do not have a job, they are not able to contribute to increasing the production of goods and services. Unemployment means that the country produces less GDP than full employment.

There are different conceptions of the natural rate of unemployment within which it is assessed: by defining a long-term trend in the unemployment rate; pro-ceeding from the idea of the equilibrium (stationary) state of the labor market, when the share of the dismissed corresponds to the share of the employed; for reasons of unemployment.
Therefore, the natural level of unemployment can be determined by knowing its causes. Following the approach suggested by M. Friedman and M. Phelps in 1960, natural unemployment is the difference between actual and cyclical unemployment. If cyclical unemployment $\left(u^{c}\right)$ estimates the number of dismissed for economic reasons (in \% of economically active population) and use data on actual unemployment $(\mathrm{u})$, then the calculation of natural unemployment $\left(\mathrm{u}^{*}\right)$ is simple: $u^{*}=u-u^{c}$. Accordingly, the "effective" number of employed in natural unemployment $\left(L_{e f}^{p}\right)$ will be: $L_{e f}^{p}=L_{e f}+U_{e f}^{c}$, Ae $U_{e f}^{c}=\sum U_{x, s}^{c} * q_{x, s} ; U_{x, s}^{c}$ - the number of economic $(\mathrm{x})$ arld gender $(\mathrm{s})$ dismissed for economic reasons.

To further calculate the potential GDP for the period 2010-2016, we substitute the found production function (3): 1) the actual capital stock $(\mathrm{K})$ in the relevant year (i). That is, the GFCF, which participates in social production, does not change ( $K_{i}=$ const, $\left.a \Delta K_{i}=100 \%\right) ; 2$ ) the potential growth of the "effective" amount of labor, which will be found by the formula: $\Delta_{\%} L_{e f}^{p}=L_{e f}^{p} / L_{e f}{ }^{*} 100$.

Therefore, the potential GDP growth in the corresponding year $\Delta_{\%} Y_{i}$, according to the constructed production function (3) will be: $\Delta_{\%} Y_{i}^{p}=100^{0,2} *\left(\Delta_{\%} L_{e f}^{p}\right)^{0,8}$. The results of calculations of GDP losses in Ukraine from unemployment above the natural rate in 2010-2016 are presented in Table 5.

Therefore, during 2010-2016 (taking into account only the quantitative factor of labor), Ukraine lost an average of $2 \%$ of GDP annually due to unemployment, which exceeds its natural rate. Thus, the under-production of GDP in 2016 with the average annual number of unemployed 1678.2 thousand people amounted to 45648.0 million UAH or $1.9 \%$ to its actual volume.

Table 5

The calculation of GDP losses in Ukraine is above the natural rate

\begin{tabular}{|l|c|c|c|c|c|c|c|}
\hline \multicolumn{1}{|c|}{ Indicators } & \multicolumn{7}{c|}{ Period } \\
\cline { 2 - 8 } & 2010 & 2011 & 2012 & 2013 & 2014 & 2015 & 2016 \\
\hline $\begin{array}{l}\text { Actual number of "effec-tively employed" } \\
\text { (thou-sand persons), } L \text { ef }\end{array}$ & 21904.4 & 2201.1 & 22168.2 & 22213.5 & 20976.7 & 191177 & 18942.1 \\
\hline $\begin{array}{l}\text { Potential amount of “effectively employed" } \\
\text { (thousand persons), } L_{e f}^{p}\end{array}$ & 22579.6 & 22558.8 & 22614.4 & 22611.7 & 21541.5 & 19663.5 & 19388.7 \\
\hline GDP actual $(Y)$, mln. UAH. & 1079346 & 1299991 & 1404669 & 1465198 & 1586915 & 1988544 & 2383182 \\
\hline$\Delta_{\%} L_{\text {ef }}^{p}$ & 103.1 & 102.5 & 102.0 & 101.8 & 102.7 & 102.9 & 102.4 \\
\hline$\Delta_{\%} L^{p} \%$ & 102.5 & 102.0 & 101.6 & 101.4 & 102.2 & 102,3 & 101.9 \\
\hline Potential GDP $\left(Y^{p}\right)$, mln. UAH. & 1106032 & 1325926 & 1427099 & 1486259 & 1621827 & 2034281 & 2428830 \\
\hline GDP growth potential $\left(\Delta Y^{p}\right)$, mln. UAH. & 26686 & 25935 & 22430 & 21061 & 34912 & 45737 & 45648 \\
\hline GDP gap, \% & -2.5 & -2.0 & -1.6 & -1.4 & -2.2 & -2.3 & -1.9 \\
\hline
\end{tabular}


Not to mention the direct non-repayable social expenditures in the form of unemployment benefits, which for this year were estimated at 6542.7 million $\mathrm{UAH}$, which is another $0.3 \%$ of GDP.

\section{Conclusions}

The results of the study help to increase the objectivity of managerial decision-making to stimulate employment at the national level. Indeed, human contribution to economic growth in gender and age distribution gives a clear picture of the magnitude of the likely benefit of properly formed and effectively harnessed investment in programmatic measures to reduce unemployment and effectively utilize the full potential of the workforce in the national economy.

Continuation of scientific research on this issue is to improve the organizational and economic tools for overcoming unemployment in Ukraine: 1) modernization of state employment assistance programs (active employment programs with the participation of the State Employment Service and within the State targeted programs and infrastructural projects) and sectoral programs, including: sheltered employment programs for specific categories of population (young people, women with young children, the disabled, pensions) Ner, etc.); 2) improvement of structural, financial, credit, investment, innovation, tax, regulatory, migration, etc. policy makers in terms of their impact on the employment sector to effectively utilize the full potential of the workforce. In addition, this requires information support, which is: 1) improvement of the information and statistical base on monitoring (problems and development) of the labor market and forecasting parameters of economic development by industry; 2) continuous development of social partnership - dialogue between representatives of central and local authorities, employers, trade unions, academics and public organizations. On the basis of which, a qualitative forecast of labor market demand and supply will be made.

\section{References:}

Agabekova, N. V. (2006). Ekonomicheskaya effektivnost zhiznedeyatelnosti naseleniya: metodologiya $i$ praktika otsenki: monografiya [Economic efficiency of the population: methodology and evaluation practice]. Minsk: BSEU. (in Russian)

Bosworth, B., \& Collins, S. (2003). The Empirics of Growth: An Update. Brookings Papers on Economic Activity, vol. 2, pp. 113-206.

Keyns, J. M. (2002). Obschaya teoriya zanyatosti, protsenta $i$ deneg [The general theory of employment, interest and money]. Moscow: Helios ARV. (in Russian)

Rodionova, I. F., \& Usyk, V. I. (2015). Makroekonomichnyi analiz natsionalnoi ekonomiky: pidruchnyk [Macroeconomic analysis of national economy]. Kyiv: Znannia. (in Ukrainian)

Sagradov, A. A. (2005). Ekonomicheskaya demografiya. Uchebnoe posobie [Economic demography]. Moscow: INFRA. (in Russian)

Ofitsiinyi sait Derzhavnoi sluzhby statystyky Ukrainy [The official website of the State Statistics Service of Ukraine]. Retrieved from: http://www.ukrstat.gov.ua/

Valkovich, E. (1970). Proizvodnyie ekonomicheskie tablitsyi smertnosti naseleniya Vengrii. Naselenie $i$ ekonomika [Age-specific economic mortality tables in Hungary. Population and economics]. Moscow. (in Russian)

Zvidrin'sh, P. P., \& Zvidrinya, M. A. (1987). Naselenie i ekonomika [Population and economy]. Moscow: Myisl. (in Russian) 